\title{
Seborrheic keratosis in the auricle
}

\author{
Junhui Jeong (ㄱ, ${ }^{1}$ Jeong Hae Kie ${ }^{2}$
}

'Otorhinolaryngology, National Health Insurance Service Ilsan Hospital, Goyang, Korea (the Republic of)

${ }^{2}$ Pathology, National Health Insurance Service Ilsan Hospital, Goyang, Korea (the Republic of)

\section{Correspondence to}

Dr Junhui Jeong;

jeongj@nhimc.or.kr

Accepted 27 January 2021

\section{DESCRIPTION}

A 69-year-old woman presented to the otorhinolaryngology clinic with a mass in the left auricle that had been present for several years. She did not have itching or pain. She had no known history of trauma or excessive exposure of the auricle to ultraviolet light. A $1 \times 0.5 \mathrm{~cm}$ brownish verrucous papillomatous lesion was observed in the cavum concha of the left auricle (figure 1).

On suspicion of malignancy, the lesion was excised completely under local anaesthesia; the resulting skin defect was minimal. Histopathologically, basaloid cell proliferation was evident in the epidermis, and acanthosis, papillomatosis and hyperkeratosis were observed (figure 2). Thus, we diagnosed seborrheic keratosis. The patient has experienced no recurrence over 1 year and 8 months.

Seborrheic keratosis is a benign cutaneous tumour that presents in the elderly as solitary or multiple round-to-oval coin-like plaques, commonly on the head, neck, trunk and extremities except the palms and soles. ${ }^{1-5}$ However, the tumour is rarely seen in the auricle and external auditory canal, ${ }^{1-5}$ and the prevalence does not differ by sex. ${ }^{45}$ Ultraviolet light exposure, human papillomavirus infection and hormonal effects are thought to be associated with tumour development. ${ }^{135}$

The histological subtypes include acanthotic, hyperkeratotic, adenoid or reticulated, clonal, irritated, inverted follicular keratosis and melanoacanthoma. ${ }^{1-5}$ The tumour should be differentiated

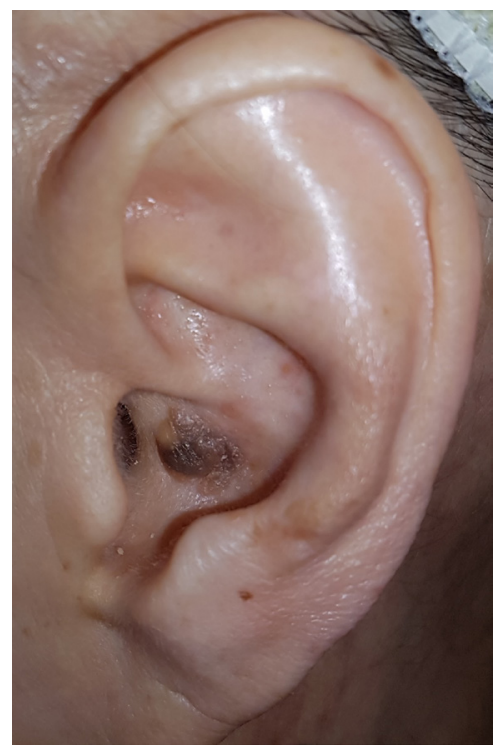

Figure 1 A $1 \times 0.5 \mathrm{~cm}$ brownish verrucous papillomatous lesion in the cavum concha of the left auricle.

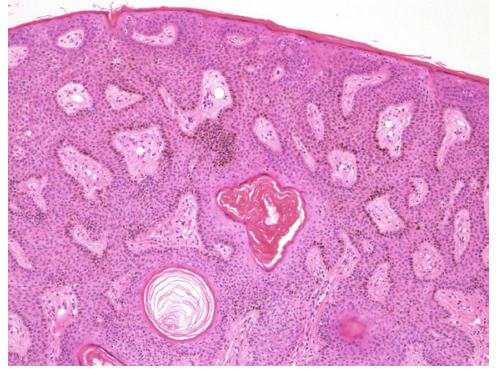

Figure 2 Histopathological image showing acanthotic proliferation of basaloid cells with papillomatosis and hyperkeratosis.

from actinic keratosis, verruca vulgaris, solar lentigo, keratoacanthoma, papilloma and malignant tumours, such as basal cell carcinoma, squamous cell carcinoma and melanoma. ${ }^{2-5}$

Treatment involves tumour removal via curettage, cryotherapy, or laser ablation, or complete excision. ${ }^{13-5}$ Close follow-up is required because it could recur and be associated with concomitant malignancy. ${ }^{35}$ With the continual ageing of society, seborrheic keratosis should be included in the differential diagnosis of papillomatous or verrucous auricle lesions in the elderly.

\section{Learning points}

Seborrheic keratosis is a benign cutaneous tumour that presents in the elderly commonly on the head, neck, trunk and extremities except the palms and soles. However, the tumour is rarely seen in the auricle and external auditory canal.

- Treatment involves tumour removal via curettage, cryotherapy, or laser ablation, or complete excision. Close follow-up is required because it could recur and be associated with concomitant malignancy.

- With the continual ageing of society, seborrheic keratosis should be included in the differential diagnosis of papillomatous or verrucous auricle lesions in the elderly.

Contributors JJ: conception and design of the work; acquisition analysis and interpretation of data for the work; drafting the article, revising the article critically; final approval for publication. JHK: conception and design of the work; acquisition, analysis and interpretation of data for the work; final approval for publication.

Funding The authors have not declared a specific grant for this research from any funding agency in the public, commercial or not-for-profit sectors.

Competing interests None declared.

Patient consent for publication Obtained. 
Images in...

Provenance and peer review Not commissioned; externally peer reviewed.

\section{ORCID iD}

Junhui Jeong http://orcid.org/0000-0002-1592-261X

\section{REFERENCES}

1 Izquierdo Velásquez JC, Campos Mahecha AM, Duarte Silva JP. Seborrheic keratosis of the external auditory canal. Otol Neurotol 2012;33:e61-2.
2 Magliulo G, Ciniglio Appiani M, Re M. Seborrheic keratosis and external auditory canal. Otol Neurotol 2012;33:e49-50.

$3 \mathrm{Kim} \mathrm{JH}, \mathrm{Kim} \mathrm{H}$, Kang JW. Dark brownish cutaneous mass in the cavum concha. JAMA Otolaryngol Head Neck Surg 2014;140:571-2.

$4 \mathrm{Kim} \mathrm{KW}$, Chang J, Lee S, et al. Clinical analysis of seborrheic keratoses in the ear: a retrospective study and literature review. Eur Arch Otorhinolaryngol 2015;272:1113-7.

5 Hong CE, Kim Y, Choi HS, et al. Seborrheic keratosis in the auricle: a rare tumor. Ear Nose Throat J 2019;98:560-1.

Copyright 2021 BMJ Publishing Group. All rights reserved. For permission to reuse any of this content visit

https://www.bmj.com/company/products-services/rights-and-licensing/permissions/

BMJ Case Report Fellows may re-use this article for personal use and teaching without any further permission.

Become a Fellow of BMJ Case Reports today and you can:

- Submit as many cases as you like

- Enjoy fast sympathetic peer review and rapid publication of accepted articles

- Access all the published articles

- Re-use any of the published material for personal use and teaching without further permission

Customer Service

If you have any further queries about your subscription, please contact our customer services team on +44 (0) 2071111105 or via email at support@bmj.com.

Visit casereports.bmj.com for more articles like this and to become a Fellow 